\title{
Microbial Load (Bacteria, Coliform and Mould Count/Flora) of Some Common Hot Smoked Freshwater Fish Species Using Different Packaging Materials
}

\author{
Olusegun Ayodele Oyelese, Jacob Oyeleye Oyedokun
}

Department of Aquaculture and Fisheries Management, Faculty of Agriculture and Forestry, University of Ibadan, Ibadan, Nigeria. Email: segunoyelese@yahoo.co.uk

Received July $13^{\text {th }}$, 2013; revised August $13^{\text {th }}, 2013$; accepted August $20^{\text {th }}, 2013$

Copyright (c) 2013 Olusegun Ayodele Oyelese, Jacob Oyeleye Oyedokun. This is an open access article distributed under the Creative Commons Attribution License, which permits unrestricted use, distribution, and reproduction in any medium, provided the original work is properly cited. In accordance of the Creative Commons Attribution License all Copyrights (C) 2013 are reserved for SCIRP and the owner of the intellectual property Olusegun Ayodele Oyelese, Jacob Oyeleye Oyedokun. All Copyright (C) 2013 are guarded by law and by SCIRP as a guardian.

\begin{abstract}
Three different packaging materials of $(37 \mathrm{~cm} \times 25 \mathrm{~cm})$ size (Sealed Transparent Polythene Bag (STPB) Sealed Paper Bag (SPB) (Brown envelope), Open Mouth Polythene Bag (OMPB) (Black incolour)) were used for Oreochromisniloticus (O), Clariasgariepinus (C) and Mormyrusrume (M). Twenty fish samples per species (averaging $250 \mathrm{gm}$ ) were hot smoked dried whole for 36 hours at an average temperature of $100^{\circ} \mathrm{C}$. Packaged hot at the rate of 6 fishes per package for each species (three packs for each packaging treatment i.e. 18 pieces were packed while the remaining 2 pieces were used for initial bacteria load and microbial load). Microbial load (Total Viable Count (TVC), Total Coliform Count (TCC) and Total Fungi Count (TFC)) for the fresh fish was initial hot smoked and finally at the end of 12 weeks was monitored. The TVC (bacterial load) of $O$. niloticus dropped from $(10.6-8.4) \times 10^{4}$ (fresh state-hot smoked) and $M$. rume $(9.8-7.0) \times 10^{4}$, while $C$. gariepinus slightly increased from $(12.4-12.6) \times 10^{4}$. After hot smoking, highest TVC of $8.6 \times 10^{4}$ (OMPBC), $8.3 \times 10^{4}(\mathrm{SPBC})$ and $8.2 \times 10^{4}$ (STPBC) was recorded in C. gariepinus among the 9 packaging at 12 weeks. However highest tendency for heavy TVC is in all OMPB with highest bacteria load in the OMPBC $\left(8.6 \times 10^{4}\right), 7.6 \times 10^{4}(\mathrm{OMPBO})$ and $6.6 \times 10^{4}(\mathrm{OMPBM})$. After 12 weeks highest ranged TFC of $(0.6-0.7) \times 10^{4}$ was recorded in M. rume as against $0.2 \times 10^{4}$ recorded in the initial smoked for all. TCC was highest in C. gariepinus (4.0 4.3) $\times 10^{4}$. Packaging did not limit the existence of micro-organisms. Six bacteria species (Micrococcus (acidiophilus, luteus), Bacillus (subtilis, cereus, aureus), Staphylococcus aureus, Streptococcus lactis, Proteus (vulgaricus, morganii), Pseudomonas aureginosa) and three fungi species (Aspergillus (niger, tamari), Rhizopusnigricans, fusariumoxysporum) were represented in all the packages. On the average five bacteria and two fungi species were represented, excepting for OMPBM and OMPBO with six bacteria species.
\end{abstract}

Keywords: Bacteria; Coliform; Mould Count/Flora; Freshwater Fish Species; Packaging Material

\section{Introduction}

Bacteria are unicellular microscopic organisms which occur almost everywhere in nature. Up to 1500 species of bacteria have been isolated since bacteria are living things; they acquire a source of food, moisture and suitable temperature to grow, when these conditions are adequate. Bacteria cause spoilage of improperly dried fish by multiplying inside the fish flesh thereby causing putrefaction. Once bacteria spoilage sets in there it is hard to remedy. The result of bacteria attack is off odour and flavor and when pathogenic bacteria are involved, it could result in illness to consumer [1].

The bacteria that most often involved in the spoilage of fish are part of the natural flora of the external slime of fishes and their intestinal content [2]. They lamented that the predominant kinds of bacteria causing spoilage vary with the temperatures at which the fish are held as follows:

- Chilling temperature

Species of pseudomonas

Achromebacter and

Flavobacterium

- Higher temperature

Genera micrococcus and 
Bacillus

- Atmospheric temperature

Escherichia

Proteus

Serratia

Sarcina and

Clostridium

Bacteria are unicellular microscopic organisms which occur almost everywhere in nature [1]. Up to 1500 species of bacteria have been isolated since bacteria are living things. They acquire a source of food, moisture and suitable temperature to grow [3], when these conditions are adequate. Bacteria will grow by a process known as Binary Fission in which the cell divides into two new cells. Some bacteria causing fish spoilage might have a generation time of 20 minutes at $30^{\circ} \mathrm{C}$ [1]. In such a case, a single bacterium may give billions in 10 hours [4].

Whilst increase in the population of micro-organisms by geometric progression is theoretically possible, its practical application is limited by environment factors prevailing. These factors are:

1) Temperature

Table 1 below shows the ranges of temperature for the growth of micro-organism.

2) Water Content

Table 2 shows the minimum water activity for the growth of micro-organism.

3) Acidity or Alkalinity $(\mathrm{pH})$

Bacteria grow well over a wide range of hydrogen ion concentration $\mathrm{pH}$ ranging from 4.0 - 9.0. The optimum $\mathrm{pH}$ growth for most bacteria lies between $\mathrm{pH} 6.5$ and 7.5 although some bacteria are capable of growing at the

Table 1. Temperature ranges for growth of micro-organism.

\begin{tabular}{cccc}
\hline Types of micro-organism & $\begin{array}{c}\text { Minimum } \\
\left({ }^{\circ} \mathrm{C}\right)\end{array}$ & $\begin{array}{c}\text { Optimum } \\
\left({ }^{\circ} \mathrm{C}\right)\end{array}$ & $\begin{array}{c}\text { Maximum } \\
\left({ }^{\circ} \mathrm{C}\right)\end{array}$ \\
\hline Psychrophiles & 0 & $15-25$ & 30 \\
Mesophiles & 10 & 37 & 43 \\
Thermopliles & 25 & $50-65.5$ & 85 \\
\hline
\end{tabular}

Table 2. Minimum water activity for growth of micro-organism [5].

\begin{tabular}{cc}
\hline Micro-organism & Minimum water activity \\
\hline Normal bacteria & 0.90 \\
Normal yeast & 0.88 \\
Normal moulds & 0.80 \\
Halophilic bacteria & 0.75 \\
Dryness resistant moulds & 0.05 \\
Osmotic pressure resistant yeast & 0.61 \\
\hline
\end{tabular}

extremes of the $\mathrm{pH}$ ranges. Bacteria growth and toxin production are inhibited if the conditions are more lethal to micro-organisms than alkaline [6].

4) Nutrient Composition

Bacteria are living organisms and like other living things such as plants and animals, they require a source of energy to survive. Such energy can be obtained from sunlight or by breakdown of nutrients which are mainly carbohydrates, proteins, fats and oil, vitamins and other growth factors. The breakdown of each of these nutrients requires the possession of the appropriate enzymes by bacteria $[1,6]$.

\subsection{Bacterial in Smoked Fish}

Smoked fish and shellfish products can be a source of microbial hazards including listeria monocytogenes, Salmonella species and Clostridium botulinium, L. mnonocytogens has been identified in several food borne outbreaks, in which pasteurized milk, coleslaw and soft cheese were implicated [7]. These organisms have also been isolated from a variety of fish and shellfish products [8].

\subsection{Fungal Attacks in Smoked Fish}

Insufficient dried fish (still containing approximately $40 \%$ moisture) especially at the processing location are prone to fungal infection, principally from the non-specific Penicillium spp., Aspergillus spp. Substantial qualities of fish are usually discarded during drying due to fungal growth. Fungal spp. also associated with smoked fish include: Aspergillus fumigates, Absidia spp., Rhizopus spp., Mucor spp., Cladosporium spp. [9-12]. It was observed that though smoking fish provides longer shelf life than other preservative methods, smoking will be effective if properly done (especially to reduce packaging).

Adebayo-Tayo et al. [9] identified 12 different fungi and aflatoxin B1 and G1 in three main markets in Nigeria on smoked dried fish with moisture content ranging from $22.7 \%-27.6 \%$. He said the level of infestation might be due to high percentage of moisture content of the smoked fish.

\section{Materials and Methods}

\subsection{Collection of Samples $\backslash$ Packaging}

Twenty pieces (sample) of each fish species of average weight 250 grams were collected for Oreochromisniloticus (O), Clariasgariepinus (C) and Mormyrusrume (M). Also fresh samples were collected for the initial proximate analysis while the remaining fresh fishes were transported to the processing unit for smoking. After 
which the initial proximate analysis of the hot smoked fish was also taken before packaging in the $37 \mathrm{~cm} \times 25$ $\mathrm{cm}$ packaging materials for each of the smoked fish species (using each of the three different packaging material for each fish species) at the rate of six (6) fish species per package and labeled e.g. for Oreochromis (STPBOSealed Transparent Polythene Bag Oreochromis, SPBOSealed paper Bag Oreochromis, OMPBO-Open Month Polythene Bag Oreochromis.

\subsection{Hot Smoking of the Fish Species}

The smoking kiln was locally improvised. Three broken blocks each of $0.3 \mathrm{~m}$ height was used to raise the wire gauze (on which the fish were laid) to avoid direct contact with fire. Big wire gauze of mesh size $2 \mathrm{~cm}$ was set on the fire when the fire was fully lit. The three species of the fish to be smoked were placed on the gauze. Big aluminum basin with a opening at the centre was used to cover the fish species in order to conserve the fire. It was through the opening that the temperature of the smoking kiln (chimney) was taken daily, until the three fish species were hot smoked dried. Hot smoking was done for 36 hours (this was achieved in three days at an average of 12 hours smoking per day) at an average temperature of $100^{\circ} \mathrm{C}$.

Hot smoking was done with an exotic hard wood (Eucalyptus species), collected from the Forestry Department of the University of Ibadan. Turning of the fish species were done at the same time to maintain uniform drying $/$ smoking at an interval of one hour (1.5 hr) thirty minutes for 3 days.

\subsection{Packaging and Shelfing}

After three days of intensive smoking, each species of the three freshwater fish species were packaged under three different packaging materials (Sealed Transparent Polythene Bag (STPB), Sealed Paper Bag (SPB) (Brown envelope), Open Mouth Polythene Bag (OMPB) (Black in colour)) under room ambient temperature range of $25^{\circ} \mathrm{C}-32^{\circ} \mathrm{C}$ for 12 weeks. Mould growth: insect infestation was checked daily during this period for each of the fish species.

The three different materials used were:
A. Sealed Transparent Polythene Bag (STPB)
1. Tilapia (Oreochromisniloticus) (STPBO)
2. Clariasgariepinus (STPBC)
3. Mormyrusrume (STPBM)
B. Sealed Paper Bag (SPB)
1. Tilapia (Oreochromisniloticus) (SPBO)
2. Clariasgariepinus (STBC)
3. Mormyrusrume (STBM)
C. Open Mouth Polythene Bag (OMPB)

1. Tilapia (Oreochromisniloticus) (OMPBO)

2. Clariasgariepinus (OMPBC)

3. Mormyrusrume (OMPBM)

The fishes were packaged hot in the packaging bags and stored in the laboratory for 12 weeks.

\subsection{Preparation of Media}

All analytical procedures in this study are according to the A.O.A.C [13].

\subsubsection{Nutrient Agar}

Twenty eight (28) grams of powdered commercially prepared of nutrient agar was weighed on Analytical metller balance into a clean dry 1 litre conical flask and $1000 \mathrm{ml}$ of distilled water placed inside a water bath set about $90^{\circ} \mathrm{C}$, allow the agar to dissolve. Distribute them into MacCantney bottles and placed them inside autoclave and set the autoclave at $121^{\circ} \mathrm{C}$ for 15 mins.

\subsubsection{Macconkey Agar (Mcca)}

Fifty five (55) grams of macConkey Agar was weighted into a 1 litre capacity of conical flask and brings to boil to dissolve the agar. Distribute them into Mac Cartney bottles and autoclave as for Nutrient Agar.

\subsubsection{Potato Dextrose Agar (PDA)}

Thirty nine (39) grams of PDA was weighted into a 1 litre capacity of conical flask bring to boil and distributed them into Mac Cartney bottles and placed them inside an autoclave as for Nutrient Agar.

\subsection{Pouring of Plates}

After autoclaving the media were placed inside a water bath set at $45^{\circ} \mathrm{C}$ to maintain the media in a molten state.

$1 \mathrm{~g}$ each of the sample was weighed into a test-tube containing $9 \mathrm{ml}$ of sterile distilled water and serially dilute them until you reach your dilution factor (10-5) and plate out $1 \mathrm{ml}$ of the last dilution factor into a sterile plates (sterilized by placing them in an over set at $160^{\circ} \mathrm{C}$ for an hour). Pour the media individually i.e. Nutrient Agar, Mac Conkey Agar and Potato Dextrose Agar into a separate plate i.e. each sample will have 3 plates and they were duplicated.

After solidifying the plates were incubated in an incubator set at $370^{\circ} \mathrm{C}$ for Nutrient Agar and Mac Conkey Agar while the potato Dextrose Agar was incubated at $280^{\circ} \mathrm{C}-30^{\circ} \mathrm{C}$. All the plates were incubated invertedly.

\subsection{Microbial Count}

The plate was counted at 48 hours for Nutrient Agar and Mac Conkey Agar while it was read for potato Detrose Agar t 72 hours. 


\subsection{Lactic Acid Bacterial Count}

Fifty five (55) grams of Man De Rogsa and shape medium (MRS) was weighed as for the above nutrient agar preparation procedures.

\subsection{Statistical Analysis}

Analysis of Variance (ANOVA) in completely randomized design was performed on the data obtained using SPSS (2006). Significant means were compared at 5\% probability level using Duncan's New Multiple Range Test (DMRT) as provided in the same SPSS (2006).

\section{Result}

As shown in Table 3 the microbial load varied significantly $(\mathrm{P}<0.05)$ among the three species. In the fresh fish the highest TVC of $12.4 \times 10^{4}$ was recorded in $C$. gariepinus, this is followed by $O$. niloticus with $10.6 \times$ $10^{4}$ and lastly $M$. rume $9.8 \times 10^{4}$. However while TFC was zero in the fresh fish for the three fish species, high- est TCC of $0.8 \times 10^{4}$, was recorded for $O$. niloticus, followed by C. gariepinus $\left(0.4 \times 10^{4}\right)$ and lastly $M$. rume with TCC of $0.3 \times 10^{4}$.

Table 4 and Figure 1 show that the TVC of O. niloticus dropped from $10.6 \times 10^{4}$ (in the fresh state) to $8.4 \times$ $10^{4}$ in the initial hot smoked and M. rume dropped from $9.8 \times 10^{4}$ (fresh state) to $7.0 \times 10^{4}$ after hot smoking, while the TVC of $C$. gariepinus slightly increased from $12.4 \times 10^{4}$ in the fresh state to $12.6 \times 10^{4}$ after hot smoking. While TFC increased from zero to $0.2 \times 10^{4}$ for the three fish species; highest TCC of $9.8 \times 10^{4}$ was recorded in C. gariepinus, followed by $4.2 \times 10^{4}$ in $O$. niloticus and lastly $3.0 \times 10^{4}$ in M. rume.

Table 5 shows that the least bacteria load (TVC) was recorded in the SPBM and STPBM, both recording TVC $6.4 \times 10^{4}$ in each case. Generally highest TVC of $8.6 \times$ $10^{4}$ (OMPBC), $8.3 \times 10^{4}$ (SPBC) and $8.2 \times 10^{4}$ (STPBC) were recorded in all $C$. gariepinus among the nine packages at the end of 12 weeks storage/packaging. Next is $O$. niloticus packaging $7.6 \times 10^{4}$ (OMPBO), $7.4 \times 10^{4}$ (STPBO) and $7.2 \times 10^{4}$ (SPBO) and lastly M. rume $6.6 \times$

Table 3. Microbial load of fresh fish samples.

\begin{tabular}{cccc}
\hline Fish species & Total Viable Count (TVC) & Total Coliform Count (TCC) & Total Fungi Count (TFC) \\
\hline C. gariepinus & $12.4 \times 10^{4}$ & $0.4 \times 10^{4}$ & NIL \\
O. niloticus & $10.6 \times 10^{4}$ & $0.8 \times 10^{4}$ & NIL \\
M. rume & $9.8 \times 10^{4}$ & $0.3 \times 10^{4}$ & NIL \\
\hline
\end{tabular}

Table 4. Microbial load of initial hot smoked fish.

\begin{tabular}{cccc}
\hline Fish species & Total Viable Count (TVC) & Total Coliform Count (TCC) & Total Fungi Count (TFC) \\
\hline C. gariepinus & $12.6 \times 10^{4}$ & $9.8 \times 10^{4}$ & $0.2 \times 10^{4}$ \\
O. niloticus & $8.4 \times 10^{4}$ & $4.2 \times 10^{4}$ & $0.2 \times 10^{4}$ \\
M. rume & $7.0 \times 10^{4}$ & $3.0 \times 104$ & $0.2 \times 10^{4}$ \\
\hline
\end{tabular}

Table 5. Final microbial load at the end of twelve weeks storage/packaging of the three hot smoked freshwater fish species.

\begin{tabular}{|c|c|c|c|}
\hline Fish species & Total Viable Count (TVC) & Total Coliform Count (TCC) & Total Fungi Count (TFC) \\
\hline SPBC & $8.3 \times 10^{4}$ & $4.0 \times 10^{4}$ & $0.6 \times 10^{4}$ \\
\hline ОМРВС & $8.6 \times 10^{4}$ & $4.3 \times 10^{4}$ & $0.6 \times 10^{4}$ \\
\hline STPBC & $8.2 \times 10^{4}$ & $4.2 \times 10^{4}$ & $0.5 \times 10^{4}$ \\
\hline SPBO & $7.2 \times 10^{4}$ & $3.8 \times 10^{4}$ & $0.4 \times 10^{4}$ \\
\hline ОМРВО & $7.6 \times 10^{4}$ & $3.4 \times 10^{4}$ & $0.3 \times 10^{4}$ \\
\hline STPBO & $7.4 \times 10^{4}$ & $3.3 \times 10^{4}$ & $0.5 \times 10^{4}$ \\
\hline SPBM & $6.4 \times 10^{4}$ & $3.2 \times 10^{4}$ & $0.6 \times 10^{4}$ \\
\hline OMPBM & $6.6 \times 10^{4}$ & $3.1 \times 10^{4}$ & $0.7 \times 10^{4}$ \\
\hline STPBM & $6.4 \times 10^{4}$ & $3.2 \times 10^{4}$ & $0.7 \times 10^{4}$ \\
\hline
\end{tabular}


$10^{4}$ (OMPBO), $6.4 \times 10^{4}(\mathrm{SPBM})$ and $6.4 \times 10^{4}(\mathrm{STPBM})$ respectively. However all the OMPB packages (Open Mouth Polythene Bag)—OMPBC $\left(8.6 \times 10^{4}\right)$, OMPBO $\left(7.6 \times 10^{4}\right)$ and OMPBM $\left(6.6 \times 10^{4}\right)$ had the highest bacteria load in each of the 3 fish species. However the highest ranged fungi (TFC) of $0.6 \times 10^{4}-0.7 \times 10^{4}$ was recorded in M. rume. This is followed by C. gariepinus with $0.5 \times 10^{4}-0.6 \times 10^{4}$ while least TFC range of $0.3 \times$ $10^{4}-0.5 \times 10^{4}$ was recorded in O. niloticus. TCC was highest in C. gariepinus ranging from $4.0 \times 10^{4}-4.3 \times$ $10^{4}$ followed by $O$. niloticus $\left(3.3 \times 10^{4}-3.8 \times 10^{4}\right)$ and lastly $M$. rume $\left(3.1 \times 10^{4}-3.2 \times 10^{4}\right)$ respectively.

Generally $M$. rume was the best packaged in terms of bacteria load (TVC) with the least range of $\left(6.4 \times 10^{4}\right.$ $\left.6.6 \times 10^{4}\right)$ followed by $O$. niloticus $\left(7.2 \times 10^{4}-7.6 \times 10^{4}\right)$ and lastly C. gariepinus $\left(8.2 \times 10^{4}-8.6 \times 10^{4}\right)$ which is the poorest in terms of bacteria loads. There were significant $(\mathrm{P}<0.05)$ differences between and within the TVC (i.e bacteria load), TCC and TFC for the three species in this study.

\section{TOTAL VIABLE COUNT (TVC)}

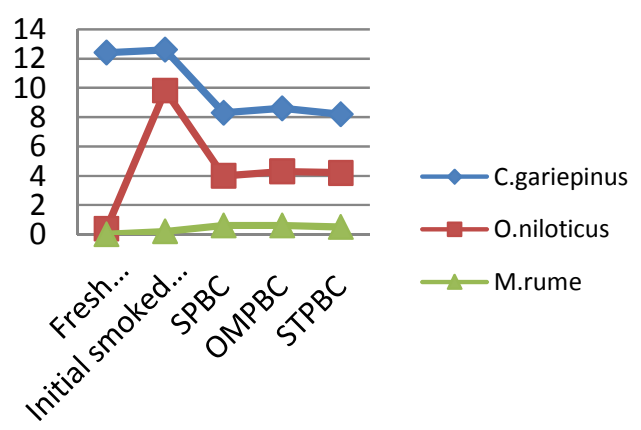

Figure 1. Total Viable Count (TVC) (Bacteria load) for the three fish species for the fresh fish, initial hot smoked and final/smoked packaged at the end of 12 weeks.
Table 6 shows that 6 bacteria species were identified in the fresh $O$. niloticus, while 5 species each were identified for C. gariepinus and M. rume in their fresh state. Also Micrococcus acidiophilus and Proteus vulgaricus were identified in the three fresh fish species under study, while Streptococcus lactis and Staphylococcus aureus were absent in C. gariepinus. However Serraticmacescenes was only present in the fresh C. gariepinus.

Table 7 shows that only C. gariepinus had only one fungi species (Rhizopusnigrica) represented in the initially hot smoked three (3) fish species. While 6 bacteria species were each represented in C. gariepinus and $M$. rume; O. niloticus had 5 bacteria species; also only Staphylococcus aureus was present throughout in the 3 initially hot smoked fish species.

Table 8 shows that only the OMPB for M. rume had 6 bacteria species and 2 fungi species, while the remaining 8 packages had 5 bacteria species and 2 fungi species. The prominent fungi species represented all the 9 packages are Aspergillu ssp (niger, tamari), Rhizopusnigricans (in SPBO, OMPBO, OMPBC, SPBM AND STPBM), WHILE Fusariumoxysporum is only represented in STPBO.

The prominent bacteria species represented in all the 9 packages are Micrococcus sp (acidiophilus and luteus), Bacillus sp (aureus, cereus andluteus). Staphylococcus aureus is present in 8 packages with the exception of OMPBO, Streptococcus lactis is also present in 8 packages excepting SPBO. Proteus sp (vulgaricus and morgani) were presented in 7 packages, excepting OMPBC and STPBM. Lastly, Pseudomonas aureginosa is present in only 3 packages (SPBO, OMPBO and OMPBC). Since micro-organisms are ubiquitous the type of pack aging (as shown in the study) will not limit their existence.

Tables 6. Bacteria species identified from the fresh three fish species.

\begin{tabular}{ll}
\hline Fish species & Micro organism \\
\hline C. gariepinus & Micrococcus acidiophilus, Bacillus cereus, Serraticmacescenes, Bacillus subtilis, Proteus vulgaricus (5 bacteria species) \\
O. niloticus & $\begin{array}{l}\text { Pseudomonas auregionosa, Streptococcus lactis, Micrococcus acidiophilus, Micrococcus luteus, } \\
\text { Staphylococcus aureus, Proteusvulgaricus (6 bacteria species) }\end{array}$ \\
M. rume & Staphylococcus aureus, Bacillus subtilis, Micrococcus acidiophilus, Proteusvulgaricus, Streptococcus lactis (5 bacteria species) \\
\hline
\end{tabular}

Table 7. Bacteria and fungi species identified from the initial hotsmoked three fish species.

\begin{tabular}{ll}
\hline Fish species & Micro organism \\
\hline C. gariepinus & $\begin{array}{l}\text { Micrococcus luteus, Bacillus cereus, Staphylococcus aureus, Streptococcus lactis, Pseudomonas aureginosa, } \\
\text { Proteus vulgaricus, } 6 \text { bacteria species + 1 fungi (Rhizopusnigrica) }\end{array}$ \\
O. niloticus & $\begin{array}{l}\text { Streptococcus lactis, Micrococcus acidiophilus, Staphylococcus aureus, Bacillus subtilis, Micrococcus acidiophilus, } \\
\text { Bacillus macerans. } 5 \text { bacteria species + Nil (0) fungi species }\end{array}$ \\
M. rume & Staphylococcus aureus, Bacillus subtilis, Micrococcus acidiophilus, Micrococcus luteus, Proteus morganii, \\
& Pseudomonas aureginosa (6 bacteria species + Nil (0) fungi species)
\end{tabular}


Table 8. Bacteria and fungi species identified from the smoked three fish species at 12 weeks of storage/packaging.

\begin{tabular}{|c|c|}
\hline Packaging & Micro-organism (bacteria and fungi species) \\
\hline SPBC & $\begin{array}{l}\text { Bacillus cereus, Streptococcus lactis, Staphylococcus aureus, Proteus vulgaricus, Micrococcus acidiophilus, } 5 \text { bacteria }+2 \text { fungi } \\
\text { species Aspergillustamari, Aspergillusniger }\end{array}$ \\
\hline OMPBC & $\begin{array}{l}\text { Staphylococcus aureus, Bacillus cereus, Micrococcus luteus, Pseudomonas aureginosa, Streptococcus lactis, } 5 \text { bacteria + } 2 \text { fungi } \\
\text { species Rhizopusnigricans, Aspergillusniger }\end{array}$ \\
\hline STPBC & $\begin{array}{l}\text { Staphylococcus aureus, Bacillus cereus, Micrococcus acidiophilus, Proteus vulgaricus, Streptococcus lactis, } 5 \text { bacteria }+2 \text { fungi } \\
\text { species Aspergillustamari, Aspergillusniger }\end{array}$ \\
\hline SPBO & $\begin{array}{l}\text { Micrococcus luteus, Bacillus subtilis, Staphylococcus aureus, Proteus vulgaricus, Pseudomonas aureginosa, } 5 \text { bacteria }+2 \text { fungi } \\
\text { species Rhizopusnigricans, Aspergillusniger }\end{array}$ \\
\hline OMPBO & $\begin{array}{l}\text { Streptococcus lactis, Micrococcus acidiophilus, Bacillus cereus, Streptococcus lactis, Proteus vulgaricus, Pseudomonas } \\
\text { aureginosa, } 6 \text { bacteria + } 2 \text { fungi species Rhizopusnigricans, Aspergillusniger }\end{array}$ \\
\hline STPBO & $\begin{array}{l}\text { Micrococcus acidiophilus, Streptococcus lactis, Proteus vulgaricus, Bacillus cereus, Staphylococcus aureus, } 5 \text { bacteria }+2 \text { fungi } \\
\text { species Aspergillusniger, Fusariumoxysporum }\end{array}$ \\
\hline SPBM & $\begin{array}{l}\text { Staphylococcus aureus, Micrococcus luteus, Bacillus macerans, Streptococcus lactis, Proteusmorganii, } 5 \text { bacteria }+2 \text { fungi } \\
\text { species Rhizopusnigricans, Aspergillustamari }\end{array}$ \\
\hline ОМРВМ & $\begin{array}{l}\text { Staphylococcus aureus, Bacillus cereus, Proteus vulgaricus, Bacillus subtilis, Streptococcus lactis, Micrococcus acidiophilus, } 6 \\
\text { bacteria + } 2 \text { fungi species Aspergillustamari, Fusariumoxysporum }\end{array}$ \\
\hline STPBM & $\begin{array}{l}\text { Micrococcus acidiophilus, Micrococcus leteus, Streptococcus lactis, Staphylococcus aureus, Bacillus subtilis, } 5 \text { bacteria }+2 \text { fungi } \\
\text { species Rhizopusnigricans, Aspergillusniger }\end{array}$ \\
\hline
\end{tabular}

\section{Discussion}

The highest bacteria load (TVC) of $12.4 \times 10^{4}$ was recorded in the fresh C. gariepinus followed by $10.6 \times 10^{4}$ in O. niloticus and lastly $9.8 \times 10^{4}$ in the fresh $M$. rume. However, initial hot smoked reduced the bacteria load of $O$. niloticus to $8.4 \times 10^{4}$ and $M$. rume to $7.0 \times 10^{4}$ while the initial hot smoked C. gariepinus TVC of $12.6 \times 10^{4}$ was not affected by hot-smoking since a slight increase of $0.2 \times 10^{4}$ was recorded after hot smoking.

Packaging had a significant $(\mathrm{P}<0.05)$ effect at 12 weeks storage/packaging of smoked fish for C. gariepinus which reduced from $12.6 \times 10^{4}$ TVC to OMPBC $\left(8.6 \times 10^{4}\right)$-SPBC $\left(8.3 \times 10^{4}\right)$-STPBC $\left(8.2 \times 10^{4}\right)$ and $M$. rume with TVC reducing from $7.0 \times 10^{4}$ (in the initial hot smoked fish) to $6.6 \times 10^{4}(\mathrm{OMPBM})-6.4 \times 10^{4}$ (SPBM) $-6.4 \times 10^{4}$ (STPBM). However all the OMPB packages (Open Mouth Polythene Bag)—OMPBC (8.6 $\times$ $\left.10^{4}\right)$, OMPBO $\left(7.6 \times 10^{4}\right)$ and OMPBM $\left(6.6 \times 10^{4}\right)$ had the highest bacteria load in each of the 3 fish species. This is also revealed in Figure 1.

Total Coliform Count (TCC) generally increased from the fresh fish sample $0.4 \times 10^{4}$ to $9.8 \times 10^{4}$ (C. gariepinus) $0.8 \times 10^{4}$ to $4.2 \times 10^{4}$ (O. niloticus) and $0.3 \times 10^{4}$ to $3.0 \times 10^{4}$ in the initial smoked (M. rume). Total Coliform Count (TCC) dropped significantly $(\mathrm{P}<0.05)$ from $9.8 \times 10^{4}$ in the initial hot smoked C. gariepinus to a range of $4.0 \times 10^{4}-4.3 \times 10^{4}$ in all the 3 C. gariepinus packaging, while TCC virtually remained the same for the $M$. rume packaging and dropped from $4.2 \times 10^{4}$ to a range of $3.3 \times 10^{4}-3.8 \times 10^{4}$ for O. niloticus at the end of 12 weeks. This is shown in Figure 2.

No Fungi count was recorded in the fresh fish sample

\section{TOTAL COLIFORM COUNT (TCC)}

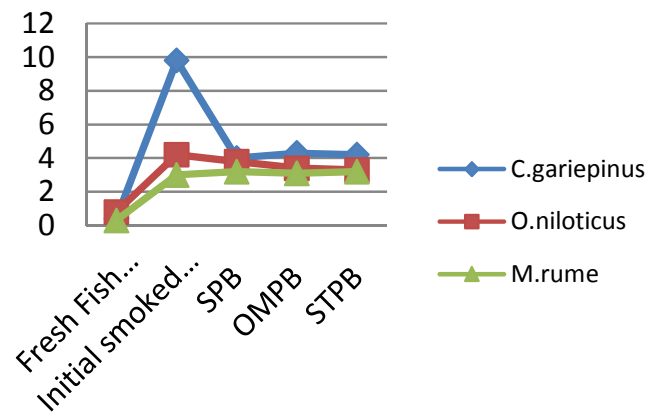

Figure 2. Total Coliform Count (TCC) for the three fish species for the fresh fish, initial hot smoked and final/ smoked packaged at the end of 12 weeks.

for the 3 fish species. However a value of $0.2 \times 10^{4}$ fungi count was recorded for the 3 fish species after initial hot smoking. This value increased; highest for $M$. rume $(0.6$ $\times 10^{4}$ to $0.7 \times 10^{4}$ ) next is $0.4 \times 10^{4}$ to $0.6 \times 10^{4}$ in $C$. gariepinus and lastly $0.3 \times 10^{4}-0.5 \times 10^{4}$ in O. niloticus. Since micro-organisms are ubiquitous the type of packaging (as shown in this study and Figure 3) will not limit their existence.

The bacterial load (TVC) count for all the three species of fish in the nine packages used for this study are below the maximum bacteria count of $5 \times 10^{5}$ cfu for good fish product according to the International Commission on Microbiology Safety for Food [14].

For C. gariepinus significant $(\mathrm{P}<0.05)$ decreases were observed in the TCC $9.8 \times 10^{4}$ in the initial smoked fish which reduced to a range of $3.1 \times 10^{4}-3.2 \times 10^{4}$ at the end of 12 weeks. This was in conformity with Wil- 


\section{TOTAL FUNGI COUNT (TFC)}

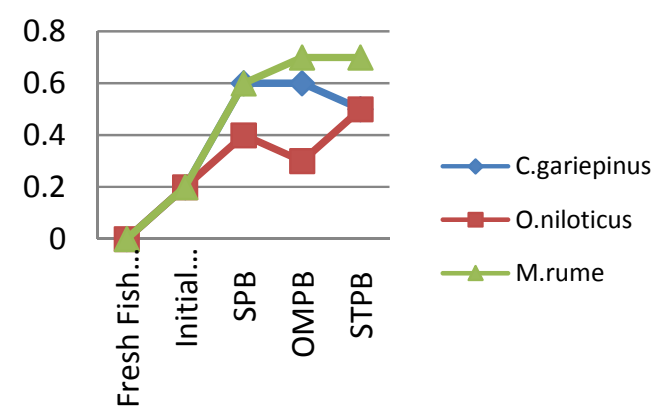

Figure 3. Total Fungi Count (TFC) for the three fish species for the fresh fish, initial hot smoked and final/smoked packaged at the end of 12 weeks.

liam, C.F and Dennis, C.W [15] who reported that the faecal coliforms count of fresh C. gariepinus fillets were similarly low after 8 days of cold storage.

Table 3 shows that there was absence of fungi in the fresh sample of the three fish species, while in Table 4 only one species of fungi (Rhizopusnigrica) was present in the initially smoked C. gariepinus. At the end of the 12 weeks of storage/packaging three (3) more fungi species (Aspergillusniger, Aspergillustamari and Fusarumoxysporum) were represented at the rate of 2 fungi species per packaging. That is fungi species were represented in all the 9 packages. The results obtained were similar to those observed by Adebayo-Tayo et al. and Fafioye, O.O et al. [9,16]. During storage of smoked fish product there was significant $(P<0.05)$ increase in the fungi count with length of storage as seen in this study. This is in line with Oyebamiji, O. F et al. and Wogu, M.D et al [11,12] who worked on stored smoked fish products marketed in the open market. The presence of fungi may be due to the difference in the chemical composition of the fish species and to which different moulds react differently $[16,17]$.

Only the OMPBM and OMPBO had 6 bacteria species represented while the remaining 7 packages had 5 bacteria species. The prominent bacteria species represented in all the nine (9) packages are Micrococcus sp (acidiophilus and luteus), Bacillus sp (aureus, cereus and luteus), staphylococcus aureus (is present in 8 packages) except in OMPBO. Streptococcus lactis also in 8 packages excepting SPBO. Others are Proteus vulgaricus, P. morganii and Pseudomonas aureginosa.

\section{Conclusion}

Highest Bacteria Count (TVC) was recorded in C. gariepinus packages among the nine packages at the end of 12 weeks. The 3 packaged fishes for $C$. gariepinus had the highest bacteria load with OMPBC (Open Mouth Polythene Bag Being the Highest). Highest tendency for heavy bacteria load (TVC) is in the Open Mouth Polythene Bag which has been confirmed in the OMPB for all the 3 fish species. Highest ranged Total Fungi Count (TFC) was recorded in M. rume followed by $O$. niloticus. Total Coliform Count (TCC) was highest in C. gariepinus followed by $O$. niloticus. Packaging did not limit the existence of micro-organisms. There were 5 bacteria species and 2 fungi species represented in each of the packages (with the exception of OMPBM and OMPBO with 6 bacteria species). The prominent fungi species represented in the 9 packages at the end of 12 weeks are Aspergillus species (niger and tamari), Rhizopusnigricans and Fusariumoxysporum. Prominent bacteria species represented in all 9 packages are Micrococcus species (acidiophilus and luteus), Bacillus species (aureus, cereus and luteus). Staphylococcus aureus is present in 8 packages (excepting OMPBO) and also Streptococcus lactis (excepting SPBO). Proteus species (vulgaricus and morganii) (in 7 packages excepting OMPBC and STPBM) and lastly Pseudomonas aureginosa are present in only 3 packages (SPBO, OMPBO and OMPBC).

\section{REFERENCES}

[1] A. A. Eyo, "Fish Processing Technology in the Tropic National Institute for Freshwater Fisheries Research (NIFFR),” New Bussa, 2001, pp. 10-170.

[2] H. I. Ibrahim, A. A. Kigbu and R. Muhammed, "Women's Experiences in Small Scale Fish Processing in Lake Fafenwa, Fishing Community, Nasarawa State,” Nigeria livestock Research for Rural Development, Vol. 23, 2011, p. 3.

[3] G. Hobbs, "Fish Handling and Processing," Ministry Of Agric, Fisheries and Food, Torry Counter, Edinburg, London, 1965, pp. 20-23.

[4] H. H. Huss, "Fresh Fish Quantity and Quality Changes," F.A.O Fisheries Series, Danish Rome, 1988, pp. 15-29.

[5] J. M. Shewan, "Bacteriological Standards for fish and Fishery Products," Chemical Industrial, Vol. 2, 1970, pp. 299-302.

[6] J. J. Conell, “Control of Fish Quality," 4th Edition, Churchhill Livingstone, Edinburg, 1995.

[7] B. W. Fleming, S. L. Cochi, K. L. MacDonald, J. Brondum, P. S. Hayes, B. D. Phkaytes, M. B. Holmes, A. Audurier, C. V. Broome and A. L Reingold, "Pasteurized Milk as a Vehicle of Infestation in an Outbreak of Lusteriosis," New England Journal of Medicine, Vol. 312, 1985, pp. 404-407. http://dx.doi.org/10.1056/NEJM198502143120704

[8] P. K. Ben Embarek, "Presence, Detection and Growth of Lusteramonocytogenes in Seafoods: A Review," International Journal of Food Microbiology, Vol. 23, No. 1, 1994, pp. 17-34. http://dx.doi.org/10.1016/0168-1605(94)90219-4

[9] B. O. Adebayo-Tayo, A. A. Onilude and U. G. Patrick, "Micro Floral of Smoked-Dried Fishes Sold in Uyo, East- 
ern Nigeria,” World Journal of Agriculture Science, Vol. 43, 2008, pp. 346-350.

[10] O. J. Abolagba and E. C. Uwagbu, “A Comparative Analysis of the Microbial Load of Smoked-Dried Fishes (Ethmalosafunbruata and Pseudotolithuselongatus) Sold in Oba and Koko Markets in Edo and Delta States, Nigeria at Different Season," Australian Journal of Basic and Applied Science, Vol. 5, 2011, pp. 500-544.

[11] O. F. Oyebamiji, T. R. Fagbohun and O. O. Olubanjo, "Fungal Infestation and Nutrient Quality of Traditionally Smoke Dried Freshwater Fish,” Turkish Journal of Fisheries and Aquatic Science, Vol. 8, 2008, pp. 7-13.

[12] M. D. Wogu and A. D. Iyayi, "Micro-Flora of Some Smoked Fish Varieties in Benin City, Nigeria,” Ethiopian Journal of Environmental Studies and Management, Vol. 4, No. 1, 2011, pp. 36-38.

[13] AOAC, “Official Methods of Analysis of AOAC Interna-

\section{Abbreviations}

TVC: Total Viable Count

TCC: Total Coliform Count

TFC: Total Fungi Count

SPBC: Sealed Paper Bag-Clariasgariepinus

OMPBC: Open Mouth Polythene Bag-Clariasgariepinus

STPBC: Sealed Transparent Polythene Bag-Clariasgariepinus

SPBO: Sealed Paper Bag-Tilapia (Oreochromisniloticus) tional," 17th Edition, Association of Analytical Communities, Gaithersburg, 2002.

[14] ICMSF, "International Commission on Microbiological Specifications for Foods. Micro-Organisms in Foods 7. Microbiological Testing in Food Safety Management," Kluwer Academic Plenum Publishers, New York, 2002, p. 199.

[15] C. F. William and C. W. Dennis, "Food Microbiology," 4th Edition, Food Science Series, Mac Grow-Hill Book Company, Singapore, 1998, pp. 243-252.

[16] O. O. Fafioye, M. O. Efuntoye and A. Osho, "Study on the Fungal Infestation of Five Traditionally Smoked Fish,” 2002.

[17] W. Reed, J. Burchard, J. Hopson, A. J Jeness and I. Yaro, "Fish and Fisheries of Northern Nigeria," Gaskiya Corporation, Zaria, 1967, 226 p.

OMPBO: Open Mouth Polythene Bag-Tilapia (Oreochromisniloticus)

STPBO: Sealed Transparent Polythene Bag-Tilapia (Oreochromisniloticus)

SPBM: Sealed Paper Bag-Mormyrusrume

OMPBM: Open Mouth Polythene Bag-Mormyrusrume

STPBM: Sealed Transparent Polythene Bag-Mormyrusrume 